\title{
論 交および報告
}

\section{溶接機用電磁スイッチについで*}

\author{
大塚郁夫** 中尾真** 初芝武美**
}

\section{On the Electromagnetic Switch for the Spot Welder Use*}

By Ikuo Otsuka**, Makoto Nakao** and Takemi Hatusiba**

\begin{abstract}
When the stored energy of an electrolytic capacitor of the spot welder is discharged through the primary circuit of the welding transformer by providing an electromagnetic switch, electrical phenomena such as high frequency oscillation or arc appear between the switching contacts.

Though the high frequency oscillation is due to an electrical cause, the arc is attributable to the mechanical chattering of the contacts.

The modes of arc occurrence are analyzed and the mechanical chattering of contacts is rendered visible by means of oscilloscope.

The theoretical consideration of the chattering mechanism showing that the contact chattering is reduced by min imizing the momentum of the moving part of a switch and the contact gap length as well as by increasing the contact force, is verified by a series of experiments.
\end{abstract}

\section{I. 緒言}

電解コンデンサ放電型点溶接機では Fig. 1 に示され るごとく, 大容量のコンデンサに蓄積された電荷を溶接 変圧器の一次側に放電し, 二次側に溶接に必要な大電流 を得る.したがって放電には適当なスイッチが必要で, 現在比較的小型のものには電磁スイッチ, 大型にはイグ ナイトロンが多く用いられている. 交流機と違って主放 電スイッチに流れる電流は大き々, 放電時間は短かい.

一例をあげると, 電解コンデンサ容量 $12,500 \mu \mathrm{F}$, 充電 電圧 $500 \mathrm{~V}$ の場合, 一次側の放電電流の最大值は約 $800 \mathrm{~A}$, 放電時間は $3 \times 10^{-2} \mathrm{sec}$, 電流最大迄の時間は 5 $\times 10^{-3} \mathrm{sec}$ である. 放電スイッチとして使用上問題にな るのは閉路時で, 開路時は電流零, 電荷零と見てよい. 次に使用頻度は高く, 一日一万回以上開閉することもあ る. とくに電磁スイッチの接点の消耗ははげしく, 連続

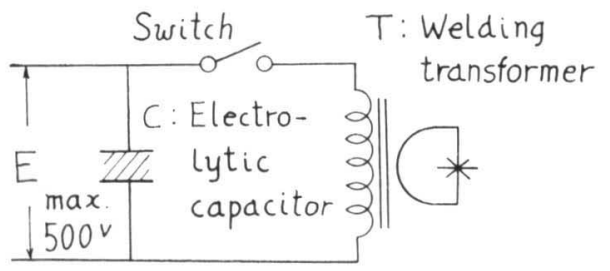

Fig. 1 Welding circuit

* 原稿受付, 昭和 36 年 9 月 4 日

** 正員, 理化学研究所 Member, The Institute of Physical and Chemical Research
使用の場合 2 〜 3 ケで接点を交換しなければならな い. この消耗は主として閉路時生ずる火花によっておこ るものであるが, 使用頻度が高い場合，スイッチ自身の 機械的損傷も重畳されると見られるので, 電磁スイッチ の開閉時に発生する現象を電気的, 機械的両面加研究 を進めた。

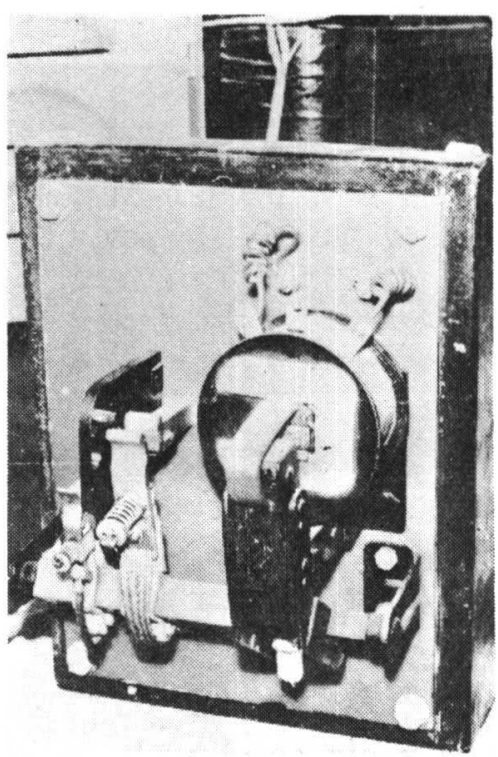

Photo. 1 Electromagnetic switch made by W. Co. Ltd. 


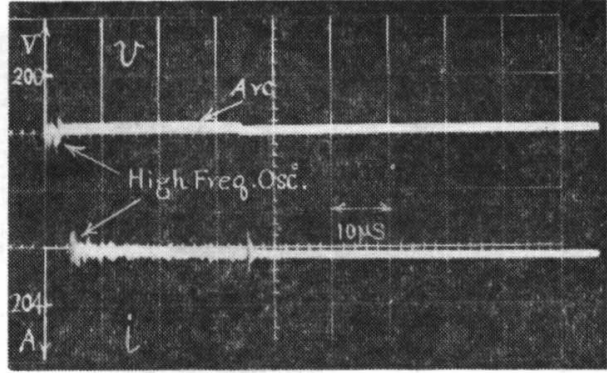

Photo. 2 Voltage and current oscillogram of contacts (1)

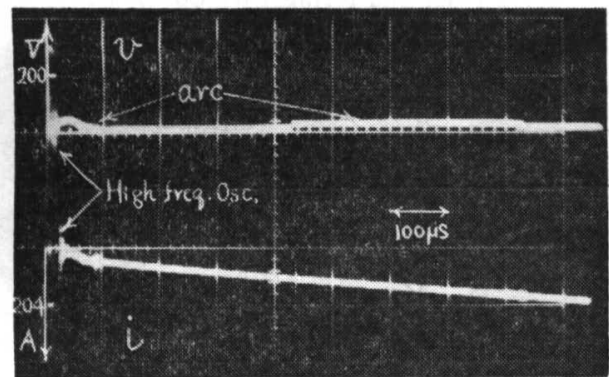

Photo. 3 Voltage and current oscillogram of contacts (2)

\section{II. 電磁スイッチの閉路時 発生する電気現象}

実験には Photo. 1 に示すW社製クラッパ型電磁スイ ッチを使用したが，交流定格 $200 \mathrm{~V}, 100 \mathrm{~A}$ で，前述の コンデンサ容量 $12,500 \mu \mathrm{F}$ の溶接機に使用しているも のである。まず高電圧 (最大 $500 \mathrm{~V}$ ) 汇充電された電荷 をこの電磁スイッチで放電した場合, その閉路時接点に 現われる電圧, および接点に流れる電流をシンクロスコ ープで観察した. 代表的なオッシログラフを Photo. 2, Photo. 3 に示した. Fig. 2 はその現象の時間的関係を 図解的に示したもので，電圧波形においては閉路の瞬 間, 高周波振動が約 $15 \mu \mathrm{s}$ 続き, これがアークに移行, $30 \mu \mathrm{s}$ 後完全閉路となるが (Photo. 2 のオッシログラフ に相当), それから約 $300 \mu \mathrm{s}$ 後ふたたびアーク電圧が 現われ，約 $400 \mu \mathrm{s}$ ほど続きふたたび完全閉路となる

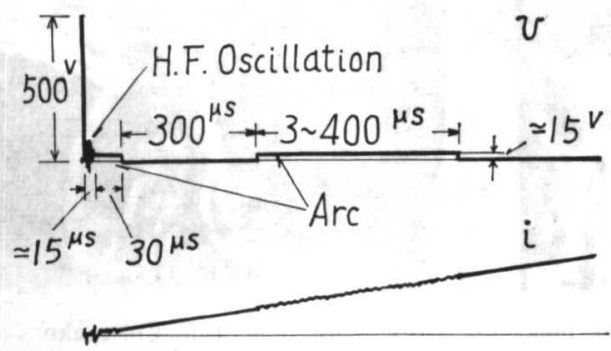

Fig. 2 Illustration of oscillogram

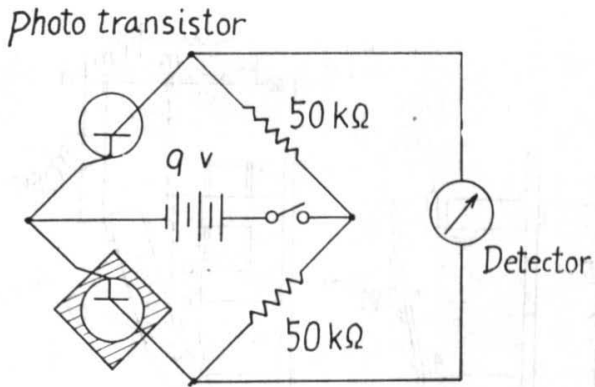

Dark box

Fig. 3 Photo-transistor detecting circuit of arc flash-light

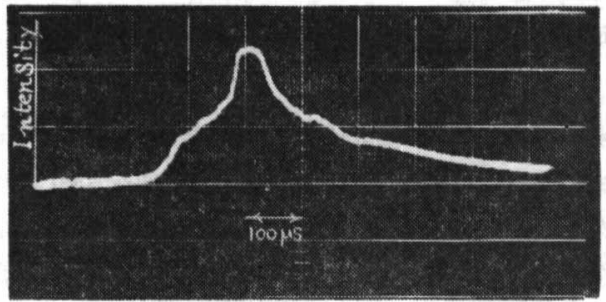

Photo. 4 Oscillogram of arc flash-light between contacts

(Photo 3 のオッシログラフに示される). 電流は回路 定数で決まる波形を示すが, 高周波電圧, アーク電圧発 生時に高周波振動が発生する．高周波振動は電気的な原 因によるが，アーク電圧の発生は接点の機械的な振動 (チャタリング) が原因している. 高周波振動の発生に ついてあ色々問題を含んでいると思われるが，ての報告 では接点の消耗を解明するので, 振動によるアーク電圧 の発生のみに着目した。すすねち接点の消耗から考える と, 第 2 番目のアーク発生時に電流が 100 200 A にむ 達しているので，乙の期間のアークによる接点の損傷が 支配的である. このととは, Fig. 3 のごときフォトト ランジスタ回路によって発光の状況を観察すると一層は っきりする. すなわち Photo. 4 のごとくなり, ちよう ど第 2 番目のアーク発生時にその発光が強く感じられ る. またての曲線は比較的長く尾を引いているが，これ は接点材料自身の発光がアーク消滅後む残っているため であろう。

\section{III. 接点振動の発生状況の観察}

接点振動の発生状況を観察するために, Fig. 4 のご とき装置で可動鉄片の動きと接点振動との関係を求め た. すなわちマグネット側にマグネットとは独立に抵抗 線を張り，可動鉄心に取付けた摺動片がその上を鉄心が 引きつけられるにつれて摺動できるようにした。したが ってこの抵抗線に電流を流しておくと, $\mathrm{mn}$ 間の電圧降 


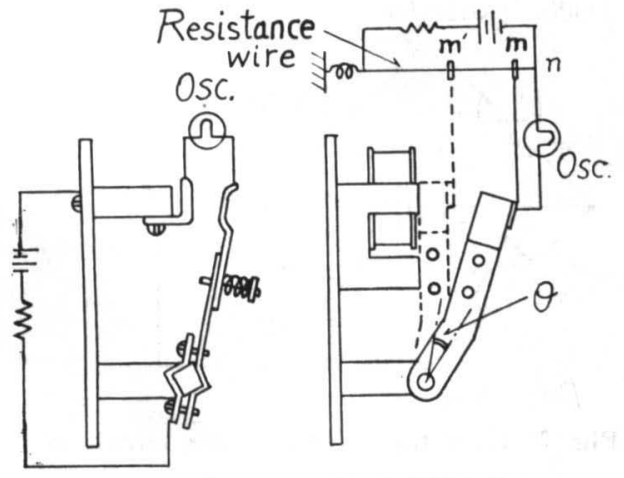

Contacter side Magnet side

Fig. 4 Wiring diagram for surveying contact chattering

下の変化によって可動鉄心の動きを代表することができ る．また接点側では接点間に $1.5 \mathrm{~V}$ の電池を $500 \Omega$ の 抵抗を通してつないでおき，接点間の電圧を観察すれ ば, 接点の開いている間は $1.5 \mathrm{~V}$ の電圧が現れるが, 閉 じると電圧は零となる．したがって振動すればそれに応 じて電圧が零と $1.5 \mathrm{~V}$ の間を振動する. Photo. 5 はそ のオッシログラフの一例で, Fig. 5 は可動鉄心の動き 之接点振動の相関関係を示した説明図である.すなわち 励磁コイルが動作すると可動鉄心は引つけられるが, 約 $25 \mathrm{msec}$ 後に可動接点が固定接点に接触し，ここで接点 の衝突による第一の振動が観察される. その後 1 1.5 $\mathrm{msec}$ 付近で可動鉄心が固定鉄心に追突する. そてで鉄 心またはスイッチ全体が振動するのが観察されるが，そ の際第二の接点振動が観察されることがある. 実験した W社製スイッチではほとんど見られなかったが，スイッ

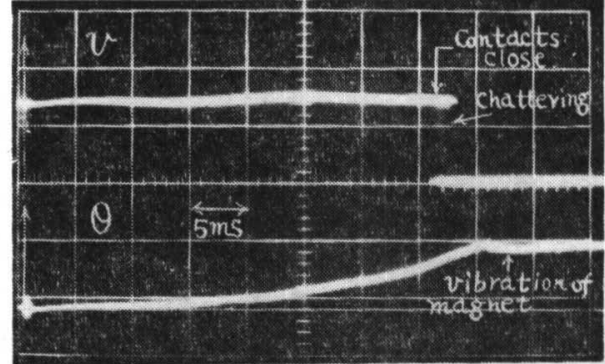

Photo. 5 Oscillogram showing the relation between magnet motion and contact chattering (W. Co. Switch)

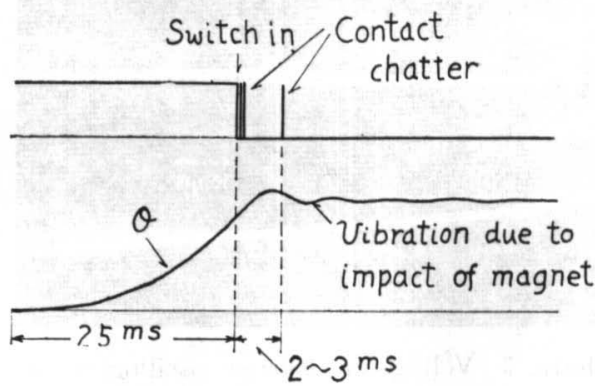

Fig. 5 Relation of contact chattering to magnet motion

チによっては第二の振動がひどく現れるものがある.

\section{IV. スイッチの連続実験}

Photo. 6 (a), (b ), (c ) に示した $\mathrm{K}$ 社製, $\mathrm{N}$ 社製, L社製の三種のスイッチを実際の溶接回路に使用して50 万回の連続放電実験を行ない, 接点およびスイッチの消 耗状況をしらべた。なお $\mathrm{K}, \mathrm{N}$ 社製はクラッパ型交流電

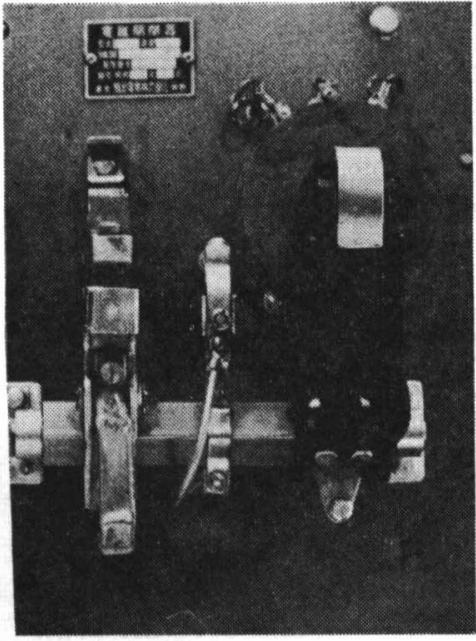

(a) Switch of K. Co. make

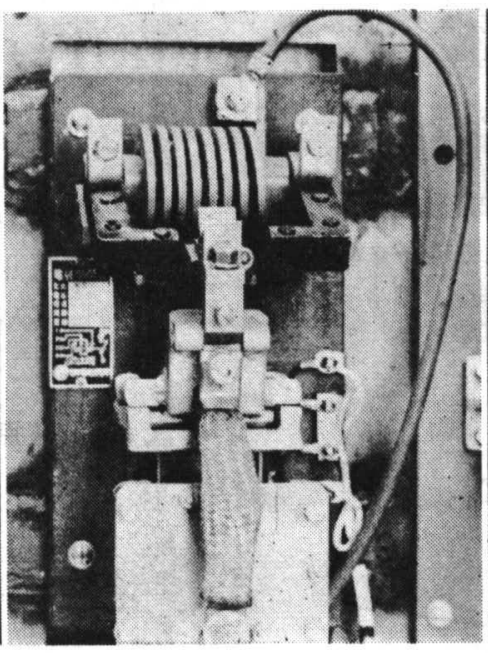

(b) Switch of N. Co. make

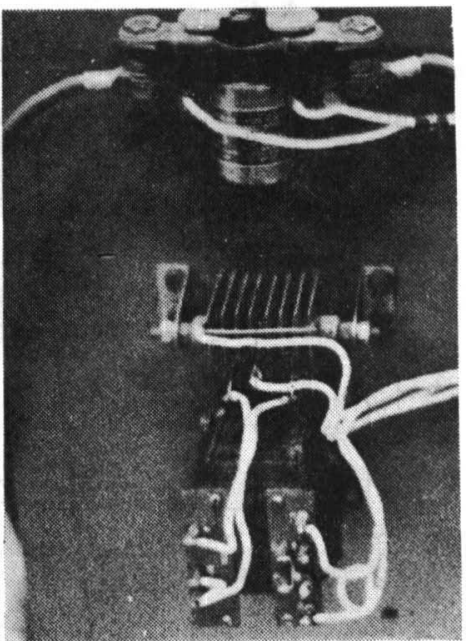

(c) Switch of L. Co. make

Photo. 6 Electromagnetic switches for running test 


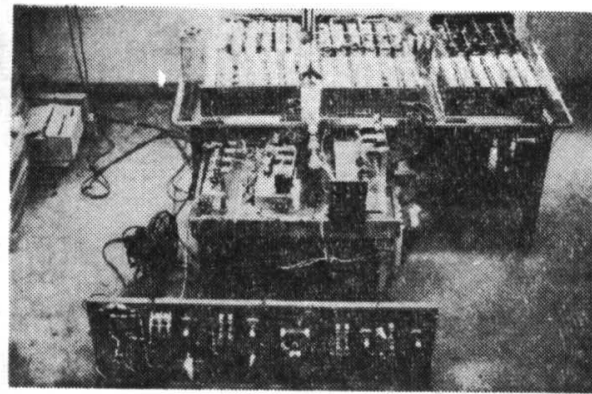

Photo. 7 The whole view of the experimental apparatus

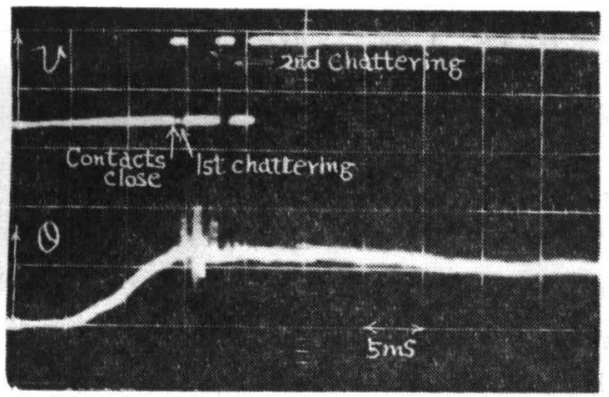

Photo. 8 Oscillogram showing the relation between contact chattering and magnet motion (K. Co. Switch)

磁スイッチで交流定格 $100 \mathrm{~A}$, 接点材料は $\mathrm{Ag}-\mathrm{W}$ 合金 であるが，L社製はソレノイド型直流電磁スイッチで, 接点容量 $200 \mathrm{~A}$, 接点材料は $\mathrm{Ag}$ であった. Photo. 7 は実験装置の全形である.

アークの発生はそれぞれ異なり， NおよびL社製はさ きのW社製のむのとほぼ同様の現象を示すが，中でも L 社製のものはスイッチ全体が小さく, 運動体のモメンタ ムが小さいので振動の発生時間が短かい，K社製スイッ チは設計上の不備から，第二の接点振動によるアークが 重思されている. Photo. 8 洼その振動の発生を説明し ているが, 明らかに第二の振動が起っている. Photo. 9 (a)，(b)，(c) はそれぞれのスイッチのアーク発生状 況を示すすのである. 50万回までの結果を Fig. 6 およ び Table に示す. 接点の消耗量は 50 万回の放電中おお よそ直線的に増加し, 発生するアークエネルギによく比 例しており，K社製スイッチが一番消耗はげしく， L社 製のものが一番優秀であった. なおスイッチに電流を通 さないで開閉のみを行なった場合の接点の消耗について は，K社製の10万回開閉後の值を示すと $0.025 \mathrm{~g}$ とな り, Table のいずれよりあはるかに少ないことがわか る.

またスイッチの回転軸, 軸受の機械的摩耗について70 万回の開閉実験によってしらべた. Fig. 7 に示すごと く軸受についてはかなり見られたが，その絶対值は小さ
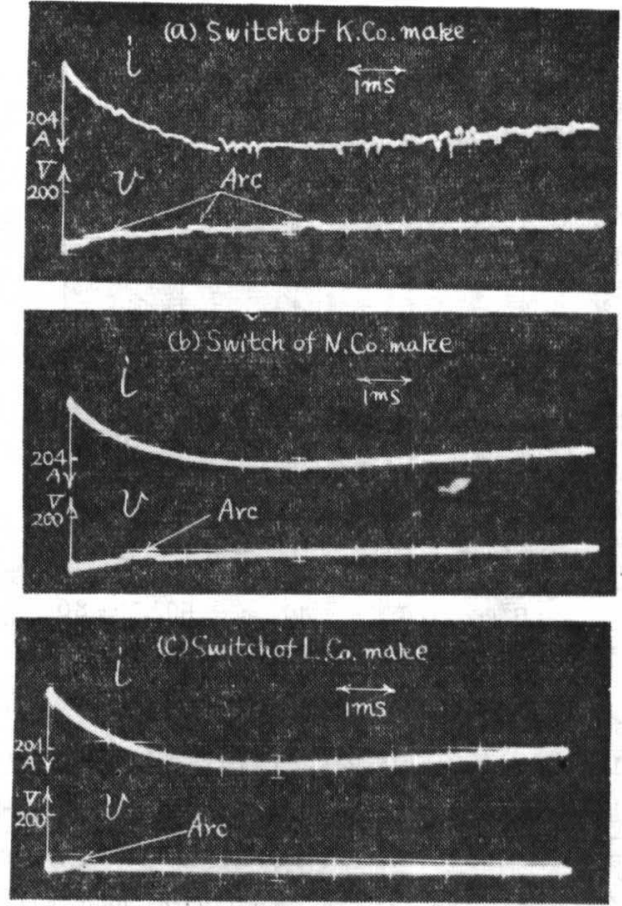

Photo. 9 Voltage and current oscillograms for three kinds of switch

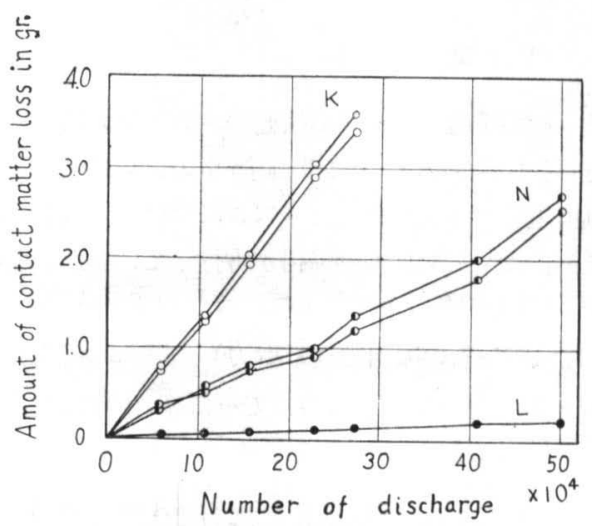

Fig. 6 Increase of contact-matter loss during repeated discharges

Table Relation between arc energy and amount of contact metter loss

\begin{tabular}{c|c|c}
\hline \hline & $\begin{array}{c}\text { Arc energy } \\
\text { in one dis- } \\
\text { charge } \\
\text { duration }\end{array}$ & $\begin{array}{c}\text { Weight loss } \\
\text { after } 27 \times 10^{4} \\
\text { times } \\
\text { discharge }\end{array}$ \\
\hline Switch of K. Co. make & 8.2 (WS) & 3.478 (g) \\
" " N. Co. " & 1.95 (" ) & 1.235 (") \\
" " L. Co. " & 0.21 (" ) & 0.149 (") \\
\hline
\end{tabular}




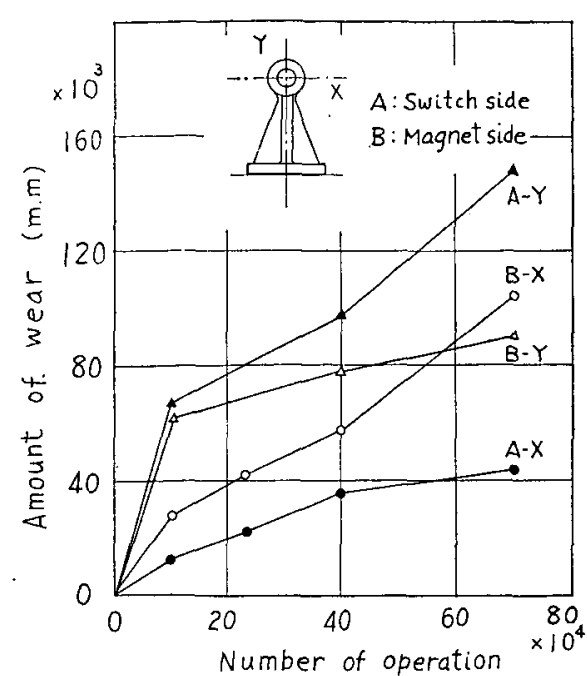

Fig. 7 Wear increase of bearing

く，100万回程度の使用に対しては接点の耗耗がそのた めに加速されるということは観察されなかった．また軸 受にナイロンブッシングを使用したすのについても比較 実験を行なったが軸受の摩耗は大差ないが，回転軸の摩 耗はほとんど見られなかった。したがって注油の必要が ないので,ナイロンブッシングの使用も面白いと考えら れる。

\section{V. 考 察}

クラッパ型電嗞スイッチの振動のメカニズムについて は古く報告りがあるが，ここでは簡単のためにンレノイ ド型直流電磁スイッチのメカニズムについて考察した。 この考察によって機械振動に何が寄与しているかが判明 したが, 設計上の条件を求めるには今な打不十分である.

i) 直流電磁不の吸引力 (率引力)

Fig. 8 のごとき電磁石についてその帝引力は次式で 示される2》.

$$
F_{t}=\left[\frac{I \omega}{4.9 L}+\left(\frac{I \omega}{3951\left(l_{0}-x\right)}\right)^{2}\right] A
$$

ただしＩははコ イルのアンペアター ン，しはイルの長 さ， $l_{0}$ は最大空げき 長，Aは鉄心の断面 皘である。

ii）可動铁心の突 入速度

(1)式で示された 率引力で可動鏃心定 含む運動体が吸引さ

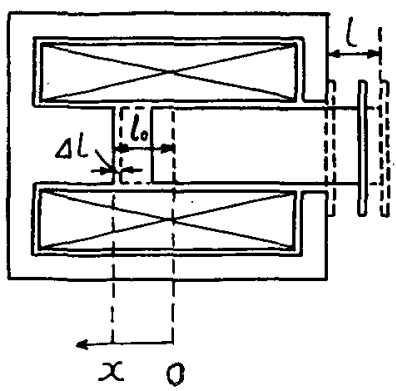

Fig. 8 Solenoid type electromagnet
それるが，の速度を求める. 今作りに（1）式で $l_{0}-x$ が小さい場合，第一项を㫮祝して埐えると，次の微分方 程式が得られる.

$$
M \frac{d^{2} x}{d t^{2}}=K \frac{1}{\left(l_{0}-x\right)^{2}}
$$

ここで $M$ は運動体の質量, $K=\left(\frac{I \omega}{3951}\right)^{2} A, x$ は $t=0$ のとき，可动鉄心の位置を0として吸引される方向の锿 さ.

$$
t=0 \text { において } \frac{d x}{d t}=0 \text { として } t \text { について皘分する }
$$
上,

$$
\begin{aligned}
& \frac{1}{2}\left(\frac{d x}{d t}\right)^{2}-\frac{K}{M} \int_{0}^{x} \frac{1}{\left(l_{0}-x\right)^{2}} d x=\frac{1}{2}\left[\frac{d x}{d t}\right]_{0}=0 \\
& \therefore \quad v=\frac{d x}{d t}=\sqrt{\frac{2 K}{M l_{0}} \frac{x}{l_{0}-x}}
\end{aligned}
$$

$x=l_{0}$ すなわち鉄心が完全に引きつけられ，空げきが 0 のとき $v$ は無限大（実際には鉄心の磁束密度 $B_{m}$ は 一定值になるので無限大とはならない：となり考察し にくいので, $\Delta l$ だけ空げきを残して鉄心が止まるよう に設計されている(または鉄心に直結した接点が固定接 点に接触する）とすると， $l_{0}-l=\Delta l$ として $x=0$ のと きの速度 $v_{0}$ は

$$
v_{0}=\sqrt{\frac{2 \bar{K}}{M}\left(\frac{1}{d l}-\frac{1}{l}\right)}
$$

iii） 反跳運動

次に鉄心江直結した接点がある位置で固定接点に追突 して跳ねかえったときの状態を考える。ここで接点追哭 後は鉄心は引きつけられたままの状態で，可䃼接点はあ るスプリングで固定接点におしつけられるとする。した がって衝突時可動接点はそのスプリング任に対抗して跳 ねかえり，スプリングを $\Delta x$ だけ扎し上げたと考える。

（Fig. 9）まず追突寸前の速度を $v_{0}$ ，追突直後の速度を $v_{1}$ とすると， $v_{1}=-e v_{0}$. こてで $e$ は反撥係数である.

次に追突後は接点の持っていた運動のエネルギがスプ リングの位置のエネルギに変換されるから, 元々 $x_{0}$ だ

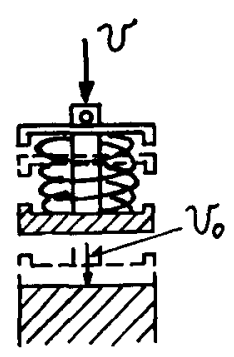

a) Before making contact

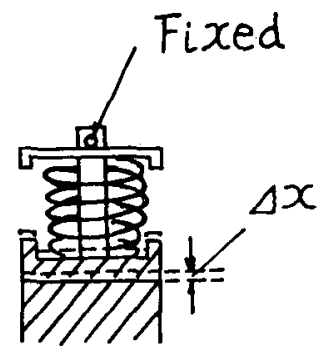

b) After making contact
Fig. 9 Contact motion before and after making 
けスプリングが圧縮されていたとすると次の式が成り立 ว.

$$
\frac{1}{2} m v_{1}^{2}=\frac{1}{2} k\left(x_{0}+\Delta x\right)^{2}-\frac{1}{2} k x_{0}^{2}
$$

ただし $m$ は接点の重量, $k$ はスプリングのバネ定数 である.（5）式で左辺は接点の運動のエネルギ, 右辺 第一項は追突後スプリングに蓄えられた全エネルギ，第 二項は追突前, すでに蓄えられていたエネルギである.

(5) 式から $\Delta x$ を求めると,

$$
\Delta x=\sqrt{x_{0}{ }^{2}+\frac{m v_{1}^{2}}{k}}-x_{0}
$$

次に接点が離れてふたたび衝突するまでの時間を計算 して見る. 接点が離れている間の運動はスプリングの単 弦振動とみなされるから, その時間は容易に求められ る.すなわち,

$$
t_{1}=2 \sqrt{\frac{m}{k}} \cos ^{-1} \frac{x_{0}}{x_{0}+\Delta x}
$$

（6）式を代入して

$$
t_{1}=2 \sqrt{\frac{m}{k}} \cos ^{-1} \frac{x_{0}}{\sqrt{x_{0}^{2}+\frac{m v_{1}^{2}}{k}}}
$$

$\cos ^{-1} \frac{x_{0}}{\sqrt{x_{0}{ }^{2}+\frac{m v_{1}^{2}}{k}}}$ の幾何学的関係を Fig. 10 に示す が, $x_{0} \gg \sqrt{\frac{m v_{1}^{2}}{k}}$ の場合は $\cos ^{-1} \frac{x_{0}}{\sqrt{x_{0}^{2}+\frac{m v_{1}^{2}}{k}}} \simeq \frac{\sqrt{\frac{m}{k}}}{x_{0}} v_{1}$ となるから

$$
t_{1}=\frac{2 m}{k} \frac{v_{1}}{x_{0}}=-\frac{2 m}{k} \frac{e v_{0}}{x_{0}}
$$

第 2 回目以下の追突によって接点の離れる時間を, $t_{2}, t_{3}, \cdots$ とすると, 離れている全体の時間は

$$
\begin{aligned}
T & =t_{1}+t_{2}+t_{3}+\cdots \cdots \\
& =\frac{2 m v_{0}}{k x_{0}} e\left(\frac{1-e^{n}}{1-e}\right)
\end{aligned}
$$

したがって振動をへらすには, $\Delta x$ すなわち $t$, または $T$ を減らすようにすればよ い.（6），(7)，（8)式加 わかるように $m v_{0}$ を減らす ことがまず考えられる， $v_{0}$ を 減らすには（4）式でlを 小さくすることが考えられ る. 次に $x_{0}$ または $k$ を大き くしてもよい.すなわち $k x_{0}$ はスプリング压に相当するの でスプリングを強くする か, スプリングにあらかじめ 十分にエネルギを蓄えておく
ことがよい.しかし，これらを実現させようとすると， その值にはおのずから限度があるし, それぞれの間に相 関関係があって制限される. 理想的には $\Delta x$ を 0 にする には、, $v_{0}$ を0にしなりればならないが，とのような構 造のスイッチでは実現はむつかしく，新しいメカニズム を採り入れなければ解決されない.

\section{VI. 可動鉄心の投入速度，スプリン グ圧の接点振動に及ぼす影響}

考察の結果を実証する例として, 可動鉄心の投入速度 とスプリング圧の接点振動に及ぼす影響をしらぺた．実 験に使用した電磁スイッチは連続実験に使用した K 社製 のもので, 前述のごとく接点振動の最もはげしいもので ある. その原因として Photo. 8 に示すごとく投入速度 が大きいこと，および接点の接触圧が $0.9 \mathrm{~kg}$ という低い 值であることがあげられるので, 投入速度を小さくし, 接触圧を増すことによって接点振動を減らすととが期待 される.

投入速度を変える方法として. 励磁コイルに加える電 圧を変えた. 接触圧は接点のスプリング圧によって変え ることができる.すなわち閉路時の接触圧が $0.9 \mathrm{~kg} の$ スプリングと, $2.2 \mathrm{~kg}$ となるスプリングとについて実験 した.

Photo. 10 はスプリング区 $0.9 \mathrm{~kg}$ で励磁電圧を 200 $\mathrm{V}, 150 \mathrm{~V}, 100 \mathrm{~V}$ と変えた場合で，振動はいぜんと現わ れるが接点の開いている時間は次第に短かくなる.

Photo. 11 はスプリング圧を $2.2 \mathrm{~kg}$ として励磁電圧 を $200 \mathrm{~V}, 160 \mathrm{~V}, 120 \mathrm{~V}$ と変えた場合で，電圧を下げて 投入速度を減らすと, 顕著に振動時間が減少しているこ とがわかる. Photo. 21 は実際に溶接回路につかってコ
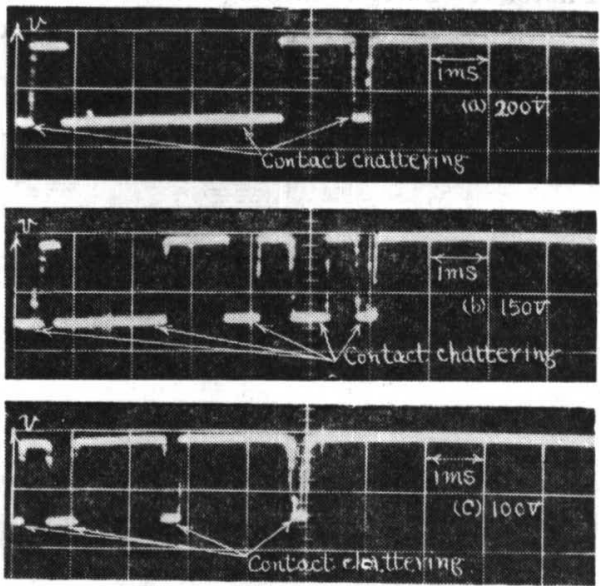

Photo. 10 Effect of exciting voltage of magnet on contact chattering (contact load ; $0.9 \mathrm{~kg}$ ) 

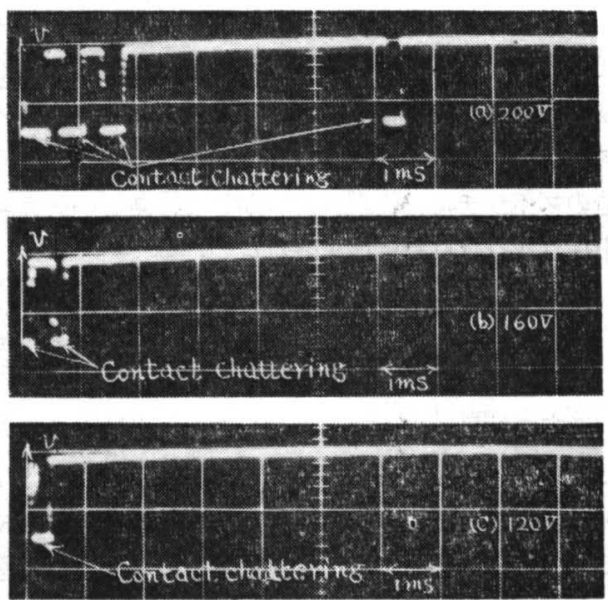

Photo. 11 Effect of exciting voltage of magnet on contact chattering (contact load ; $2.2 \mathrm{~kg}$ )
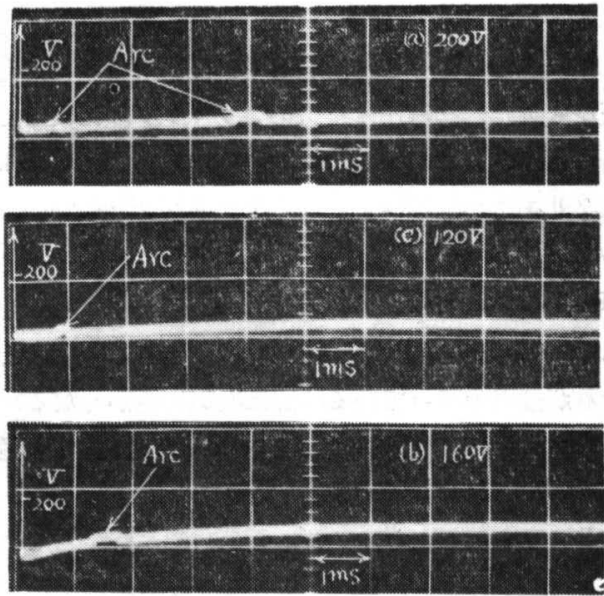

Photo. 12 Effect of exciting voltage of magnet on arc occurrence (contact load ; $2.2 \mathrm{~kg}$ )
ンデンサの電荷を放電した場合の電圧波形を示す.

\section{VII. 結言}

以上, 電解コンデンサ放電型溶接機用電磁スイッチの 閉路時に発生する電気現象をしらべ, 次のととを明らか にした. また接点振動について簡単な考察を行なった.

1）スイッチ接点消耗の原因は接点振動によって生ず るアークによるものである.

2）接点振動には, 可動接点が固定接点に追突したと きに発生する振動と, その直後可動鉄心が固定鉄心に追 突して生ずる振動が接点に伝わって発生するものとの二 種類ある.

3）同じ接点材料については, スイッチ接点の振動に よって発生するアークのエネルギと接点消耗量との間に は比例関係がある.

4） 50 万回程度の開閉使用による回転軸等の機械的摩 耗は,アーク発生には影響を与えない。

5）考察によると，接点振動をへらすには，可動接点 を含む運動体のモメンタムをへらすとと，スプリング圧 を大きくするか，スプリングに十分な位置エネルギを蓄 えることが必要である. 理想的に振動をなくすには，追 突時運動体の保有する運動のエネルギを他の機構によっ て吸収する必要がある.

6）しかし現用のスイッチでも投入速度，スプリング の接触圧を適当に選ぶことによって, 接点振動をかなり へらすととができた.

終りに御指導戴いた宮田聰博士ならびに実験上の便宜 をはかって戴いたオリジン電気株式会社溶接課に厚く感 謝する。

\section{文献}

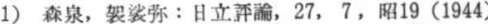

2) 電気学会 : 特䅀機器, 50 : 昭 31 (1956) 